\title{
Influence of recombinant S2 cell population enrichment on rabies virus glycoprotein expression and especific RNA and DNA quantities
}

\author{
Nayara Santos ${ }^{*}$ Carlos Pereira, Daniella Ventini-Monteiro, Ana Lia Puglia, Renato Astray \\ From 5th Congress of the Brazilian Biotechnology Society (SBBIOTEC) \\ Florianópolis, Brazil. 10-14 November 2013
}

\begin{abstract}
Background
Different strategies have been evaluated for increasing the productivity of Drosophila melonogaster (S2) cells expressing recombinant rabies virus glycoprotein (RVGP). The maintenance of selective pressure during all the cultivation time and new methods for population enrichment with high level expressing cells are two methods which can increase the productivity through increased expression of RVGP gene. To understand how these methods can improve glycoprotein expression, analysis of the quantities of heterologous DNA and RNA were performed [1,2].
\end{abstract}

\section{Methods}

From S2MtRVGPHy cell population (untreated control) three populations were generated: S2MtRVGPHy+Hy was obtained after selective pressure using hygromycin for 2 weeks; S2MtRVGPHy-M2 and S2MtRVGPHy-M3 were obtained after immunomagnetic enrichment of RVGP expressing cells (MACS, Miltenyl Biotec), using rabbit polyclonal antibody and mouse monoclonal antibody, respectively [3]. Cell populations were induced with $\mathrm{CuSO}_{4}$ for RVGP expression and submitted to cycloheximide $(\mathrm{CHX})$ treatment before sampling in different periods. Samples were analyzed by ELISA, qPCR and qRT-PCR.

\section{Results}

All cell populations presented no significative differences in RVGPDNA content as analysed by qPCR. Before treating the cultures with $\mathrm{CHX}$, cell populations showed very similar amounts of RVGPmRNA and were expressing RVGP at concentrations of 23.1, 31.9, 65.3 and 45.7 ng / $10^{6}$ cells for S2MtRVGPHy, S2MtRVGPHy-M2,

Instituto Butantan, São Paulo, SP, Brazil

2014 Santos et al : licensee BioMed Central Ltd This is an Open Access article distributed under the terms of the Creative Commons Attribution License (http://creativecommons.org/licenses/by/4.0), which permits unrestricted use, distribution, and reproduction in any medium, provided the original work is properly cited. The Creative Commons Public Domain Dedication waiver (http://creativecommons.org/publicdomain/zero/1.0/) applies to the data made available in this article, unless otherwise stated. 


\section{Acknowledgements}

Fundação para o Desenvolvimento Administrativo (FUNDAP) and Instituto Butantan.

\section{Published: 1 October 2014}

\section{References}

1. Astray RM: Expressão da glicoproteína recombinante do vírus rábico em sistemas Drosophila melanogaster (S2) e Semliki Forest Virus (SFV) $=L^{\prime}$ expression de la glicoprotéine Du vírus de la rage dans les systèmes Drosophila melanogaster (S2) et Semliki Forest Virus (SFV). Tese em cotutela apresentada ao Programa de Pós-Graduação Interunidades em Biotecnologia USP/Instituto Butantan/IPT, para obtenção do Título de Doutor em Biotecnologia 2009, 7.

2. Lemos MAN: Construção e Transfecção de vetores plasmidiais contendo o gene da Glicoproteína do Vírus da Raiva (GPV) em células de Drosophila melanogaster. Dissertação apresentada ao Programa de PósGraduação Interunidades em Biotecnologia USP/Instituto Butantan/IPT, para obtenção do Título de Mestre em Biotecnologia 2009, 70-72.

3. Miltenyi Biotec GmbH: MACS Separators user manual. MACS Miltenyi Biotec 2011, 2.2.1.2-2.2.1.4

4. Urban J, Soulard A, Huber A, Lippman S, Mukhopadhyay D, Deloche O, Wanke V, Anrather D, Ammerer G, Riezman H, Broach JR, Virgilio CDe, Hall MN, Loewith R: Sch9 Is a Major Target of TORC1 in Saccharomyces cerevisiae. Molecular Cell 2007, 26:663-674.

doi:10.1186/1753-6561-8-S4-P230

Cite this article as: Santos et al:: Influence of recombinant S2 cell population enrichment on rabies virus glycoprotein expression and especific RNA and DNA quantities. BMC Proceedings 2014 8(Suppl 4):P230.

\section{Submit your next manuscript to BioMed Central and take full advantage of:}

- Convenient online submission

- Thorough peer review

- No space constraints or color figure charges

- Immediate publication on acceptance

- Inclusion in PubMed, CAS, Scopus and Google Scholar

- Research which is freely available for redistribution

Submit your manuscript at www.biomedcentral.com/submit 